\title{
State, Society and the Cultural Cold War: A View from the Periphery
}

\author{
Zinovia Lialiouti* \\ Post-doctoral researcher, Centre for Modern Greek History, Greece
}

Submission: March 06, 2018; Published: May 31, 2018

*Corresponding author: Zinovia Lialiouti, Post-doctoral researcher, Centre for Modern Greek History, Academy of Athens, Greece, Tel: 0030 6977086683 ; Email: jennylialiouti@gmail.com

Keywords: Society; Cold war; State; Ideology; Propaganda; Literature; Cultural; History; Total conflict; Superiority; Public agencies; Historiography; Front line; Interdependence

\section{Opinion}

The Cultural Cold War literature is a fascinating research field which highlights the interaction and interdependence between ideology, culture and propaganda. A significant number of contributions in the field have renewed and deepened our understanding on the nature of the Cold War beyond the diplomatic history perspective. In this respect, it is worth citing Kenneth Osgood's conceptualization of the Cold War as a 'total conflict' in the sense that the traditional distinction in war conflicts between the 'front line' and the 'internal front' was practically eliminated and societies were involved in the waging of the war in diverse and far-reaching ways [1]. As Scott Lucas has remarked the huge military spending during the Cold War would be "meaningless if populations did not endorse and, in some cases, proselytize the values that proved their superiority" [2].

Another important contribution of the Cultural Cold War literature has been the re-examination of the relationship between state and civil society in the shaping of the Cold War. In short, research has been able to document the complex interaction between government institutions (public agencies, intelligence and propaganda mechanisms etc) - both official and unofficial - and civil society groups or private initiative. This analysis has revealed a bidirectional flow of initiatives and activities that undermines the perception of the Cold War as a top-down process totally driven and formulated by governments with the passive involvement of society in its implications. Moreover, it has convincingly made the argument that in many cases private interests, values and goals were pivotal in the actual form and content of the Cold War conflict. The above aspects of the relationship between state and society in the Cold War have been captured in the formulation of the concept "state-private network" which has generated a fruitful line of research [3].

Going a step forward recent scholar works have emphasized the primary role of transnational networks of individuals - in comparison to government policies -in promoting Cold War ideology and the anti-communist consensus in both sides of the Atlantic [4]. This perspective is in line with the shift in $20^{\text {th }}$ century historiography from the "American century" to the "transatlantic century" which also reconstructs the Cold War period as a relationship of interdependence and mutual exchanges between the New and the Old World [5].

What I would like to suggest in this note is that a coreperiphery distinction in the above formulations could be useful not as an essentialist approach but as an effort to contextualize the features of the Cold War conflict in relation to the specific historical, political, social and institutional legacies in smaller countries such as Greece. Greece's relative differentiation from these patterns of analysis will be briefly commented here not as an exceptional case, but probably as representative of a number of countries facing a weak or failed state challenge in the aftermath of WWII and/or a legacy of colonial or semi-colonial legacy in the pre-war period.

In the Greek case, the role of the state is far more important than private initiatives in the development of Cold War ideology. The initiatives of private groups in the transatlantic nexus and in the promotion of anticommunist ideology were more oriented towards the internal realm as a means of resolving in their favour conflicts and divisions already existing from the interwar period and also securing economic resources from the state than towards fulfilling goals and aspirations of truly transatlantic 
origin and perspective. In this way, transnational elements and currents were instrumentalized by national elites.

Moreover, the degree of inequality in the bilateral relationship between Greece and the US is decisive in challenging the perception of a genuine transatlantic community between the two countries. Following the end of WWII, Greece was on the verge of economic default and in the midst of a brutal civil war. The US on the other hand gradually emerged as the leader of the 'Free World' in the battle against totalitarianism; thus, Greece evolved into a 'taste case' for US leadership. With the Truman Doctrine and the Marshall Plan, US involvement in post-war Greece took the form of a state-building project aiming to the country's economic, institutional and ideological reconstruction. This strategy was also reflected in the shaping of American cultural diplomacy towards Greece and in the overall development of the Cultural Cold War in the country [6]. To conclude, the state - in the form of the American and the Greek government in their close interaction - was the decisive actor in the Cultural Cold War in the Greek case.

\section{References}

1. Kenneth Osgood (2006) Total Cold War. Eisenhower's Secret Propaganda Battle at Home and Abroad, Lawrence Kansas, University Press of Kansas, USA.
2. Scott Lucas W (1950) 'Beyond Diplomacy: Propaganda and the History of the Cold War'. In: Gary Rawnsley, Macmillan S (Eds.), Cold War Propaganda, London, UK, p. 11-30.

3. Scott Lucas (2008) Freedom's War. The US Crusade against the Soviet Union 1945-1956, Manchester University Press, Manchester 1999, 93-106. Helen Laville and Hugh Wilford ( $\varepsilon \pi \iota \mu$.), The US Government, Citizen Groups and the Cold War. The state-private network, Routledge, Oxon/ New York 2006. Hugh Wilford, The Mighty Wurlitzer: How the CIA played America, Harvard University Press, USA.

4. Luc van Dongen, Stephanie Roulin, Giles Scott-Smith (2014) Transnational Anti-Communism and the Cold War: Agents, Activities, and Networks. Palgrave Macmillan, Houndmills, Basingstoke, Hampshire, UK.

5. Mary Nolan (2012) The Transatlantic Century. Europe and America, 1890-2010, Cambridge University Press, Cambridge 2012. Giles ScottSmith, Western Anti-Communism and the Interdoc Network: Cold War Internationale, Palgrave Macmillan, Houndmills, Basingstoke, Hampshire, UK.

6. Zinovia Lialiouti (2018) Propaganda, Networks of Influence and Culture. American Cultural Diplomacy in Greece 1953-1973, University Press of Crete, Herakleion Zinovia Lialiouti, The 'treason of the intellectuals': The Shadowy presence of the Congress for Cultural Freedom in Greece, 1950-1963, Intelligence and National Security ahead of print 2018, Zinovia Lialiouti, "American Cultural Diplomacy in Greece 1953-1968",Journal of Transatlantic Studies, 15(3): 229-250.

\section{Your next submission with Juniper Publishers} will reach you the below assets

- Quality Editorial service

- Swift Peer Review

- Reprints availability

- E-prints Service

- Manuscript Podcast for convenient understanding

- Global attainment for your research

- Manuscript accessibility in different formats

( Pdf, E-pub, Full Text, Audio)

- Unceasing customer service

Track the below URL for one-step submission https://juniperpublishers.com/online-submission.php 